\title{
Experimental Study on Doweled Expansion Joints on Behavior for Plain Concrete Pavement System
}

\author{
Zainab Ahmed Al-kaissi* Mohammed Hashim Mohammed** \\ Nabaa Sattar Kareem*** \\ *,**,***Department of Highways and Transportation Engineering/Al-Mustansiriyah University \\ *Email: zainabalkaisi77@googlemail.com \\ **Email: $\underline{\mathrm{m} \_ \text {sahlani@yahoo.com }}$ \\ ***Email: eng.nabaa1992@ Gmail.com
}

(Received 26 April 2017; accepted 7 March 2018)

https://doi.org/10.22153/kej.2018.03.001

\begin{abstract}
This paper deals with load-deflection behavior the jointed plain concrete pavement system using steel dowel bars as a mechanism to transmit load across the expansion joints. Experimentally, four models of the jointed plain concrete pavement system were made, each model consists of two slabs of plain concrete that connected together across expansion by two dowel bars and the concrete slab were supported by the subgrade soil. Two variables were dealt with, the first is diameter of dowel bar $(12,16$ and $20 \mathrm{~mm})$ and the second is type of the subgrade soil, two types of soil were used which classified according to the (AASHTO): Type I (A-6) and type II (A-7-6). Experimental results showed that increasing dowel bar diameter from $12 \mathrm{~mm}$ to $20 \mathrm{~mm}$ has a little effect on load-deflection behavior of the tested specimens with only 5\% increase in failure load. This may be attributed to that the failure (caused by flexural crack) depends mainly on concrete strength. Results also showed that decreasing CBR value of subgrade soil from $7 \%$ to $5 \%$ decreases failure load by about $33 \%$.
\end{abstract}

Keywords: Steel dowel bars, jointed plain concrete pavement, load-deflection behavior, subgrade soil.

\section{Introduction}

A rigid pavement system consists of a number of concrete slabs. The concrete slabs are limited in width and length. The slabs rest on the subgrade only or subgrade and subbase but in some cases the slabs resting on subgrade, subbase and base layer. In the rigid pavement system, joints installed to supply space to accommodate horizontal movement of slab due to moisture and temperature change, and to control cracks. The pavement system requires a device of load transfer like tie bars or dowel bars. The load transfer device efficiently helps to reduce stresses of pavement and decrease deflection of loaded slab by transmit an applied load to the adjacent unloaded slab $[1,2,3]$. A jointed plain concrete pavement system exposed to the following loading cases: self-weight of the slab, wheel loads of vehicle and loads due to thermal effects of environmental due to temperature and moisture changes which causes crack of the concrete slab, load transfer devices failure like dowel bars, and loss of slab support because of temperature create curling, opening and closing joints [4].

\section{Research Significance}

In this paper, the load deflection behaviors of steel dowel bars using experimental methods for various diameter of dowel bars and subgrade soil strength and to achieve a better understanding of the load transfer mechanism. To validate the 
experimental models, the results of the loaddeflection behavior of experimental models are compared with the results of the load-deflection of numerical models.

\section{Test Methodology}

To simulate the expansion joint in plain concrete pavement system, the wooden mold is made for concrete slab casted. Net dimensions of mold are $(121 * 60 * 12.5 \mathrm{~cm})$ the models thickness was chosen according to the ACI where less pavement thickness of parking lots equal 125 mm according of ACI 330R, see Table (1). A piece of cork is used to separate the two slabs of plain concrete pavement to represent the joint between them, the cork dimensions are $(60 \mathrm{~cm})$ length, $(12.5 \mathrm{~cm})$ height and $(1 \mathrm{~cm})$ width, which represents the joint width (because these joint width is typical for expansion joints in the Middle-Eastern countries like Iraq [15]). Thus, the mold is divided into two parts. The dimensions of each part $(60 * 60 * 12.5 \mathrm{~cm})$, see Figure (1). Two holes were made in the piece of cork at $(15 \mathrm{~cm})$ distance from each edge and the distance between holes is $(30 \mathrm{~cm})$ center to center, the dowels spacing which is recommended by (ACPA) [5] specification, the hole diameter varies depending on the diameter of steel dowel bar used in specimen. In this research, the round and smooth steel dowels were used and placed in mid depth of concrete slab. the length of dowels varies with the diameter of dowels where the length of $300 \mathrm{~mm}$ for 12 and $16 \mathrm{~mm}$ dowels diameter and $350 \mathrm{~mm}$ for $20 \mathrm{~mm}$ dowel diameter, see Table (1). Before casting concrete the steel dowel bars were placed in position through the holes. As recommended by the AASHTO, ASTM, ACI and ACPA specifications, the expansion joints must be fixed in one side and free in the other, and has a cap provides a horizontal distance equal to the width of joints to allow movement of the pavement resulting from the change in temperature and moisture. Steel dowel bars were greased on the free side so as not to restrict the horizontal movement of pavement. After preparation of the mold, the casting process begins, see Figure (2).

To Simulate the subgrade soil in rigid pavement system, a subgrade soil container is made by the researcher. This container was made of $(12 \mathrm{~mm})$ thick steel plate with $(130 * 70 * 20$ $\mathrm{cm})$ internal dimensions. To represent the subgrade soil, the wet soil was dried in the air to remove the water and get the dry soil. Then the soil is cleaned, ground and sieved by a sieve (No.4). After that, the dry soil passing from sieve (No.4) with optimum moisture content were mixed by hand to get a homogeneous mixture. In the steel container, soil is placed in five layers, each layer with about $(4 \mathrm{~cm})$ thickness and each layer of soil is compacted by a steel rod, see Figure (3).

The jointed concrete pavement slabs are rested on compacted soil in a steel container and the specimens then setting on the hydraulically universal testing machine. Using a steel plate of $(60 * 8.5 \mathrm{~cm})$ dimensions, the load was applied at $(6 \mathrm{~cm})$ distance from joint edge on the slab where dowel bar is fixed to concrete. The vertical deflections were measured using two dial gages of $(0.01 \mathrm{~mm})$ accuracy (one gage at each edge of the joint). Both dial gages are placed at top surfaces of the slabs, see Figure (4). Uplifts of the far ends of concrete slabs were observed and recorded during the test. Four specimens were tested on the subgrade soil and the load was applied incrementally until the failure of specimen.

Table 1,

Dowels for Concrete Parking Lots, City Streets and Highways [16]

\begin{tabular}{lllll}
\hline Pavement & $\begin{array}{l}\text { Slab thickness } \\
\text { mm }\end{array}$ & $\begin{array}{l}\text { Dowel diameter } \\
\text { mm }\end{array}$ & $\begin{array}{l}\text { Dowel embedment* } \\
\text { mm }\end{array}$ & $\begin{array}{l}\text { Total dowel length } \dagger \\
\text { mm }\end{array}$ \\
\hline \multirow{3}{*}{ Parking lots } & $125 \ddagger$ & 15 & 125 & 300 \\
(ACI 330R) & $150 \ddagger$ & 20 & 150 & 350 \\
& $175 \ddagger$ & 25 & 150 & 350 \\
& 200 & 25 & 150 & 350 \\
& 225 & 30 & 180 & 400 \\
\hline City streets (PCA 1992) & $150 \ddagger$ & 20 & 125 & 360 \\
Jointed reinforced & $165 \ddagger$ & 22 & 125 & 360 \\
pavements with joint & $180 \ddagger$ & 25 & 150 & 400 \\
spacing greater than (6 m) & 190 & 28 & 180 & 400 \\
& 225 & 32 & 200 & 430 \\
\hline Highways & $<250$ & 30 & 190 & $450 \S$ \\
(ACPaA 1991) & $\leq 300$ & 40 & 225 & $500 \S$ \\
\hline
\end{tabular}


* On each side of joint, 6 times dowel diameter for load transfer.

$\dagger$ Includes allowance for joint opening and minor errors in positioning -2 times embedment length +2 to 3 in. (50-75 mm).

$\ddagger$ Dowels may be impractical in thinner pavements.

$\S$ Computed from recommendations in ACPaA (1991), which also states: Most agencies specify 18-in.- (450-mm-) long dowels

for typical highway pavement.

Note: Dowel spacing 12 in. $(300 \mathrm{~mm})$.

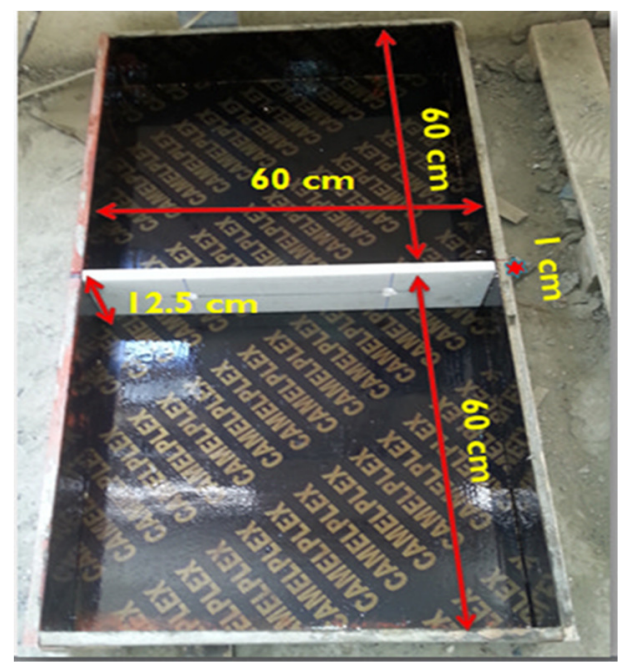

Fig. 1. The Cork Piece is used to Represent the Joint.

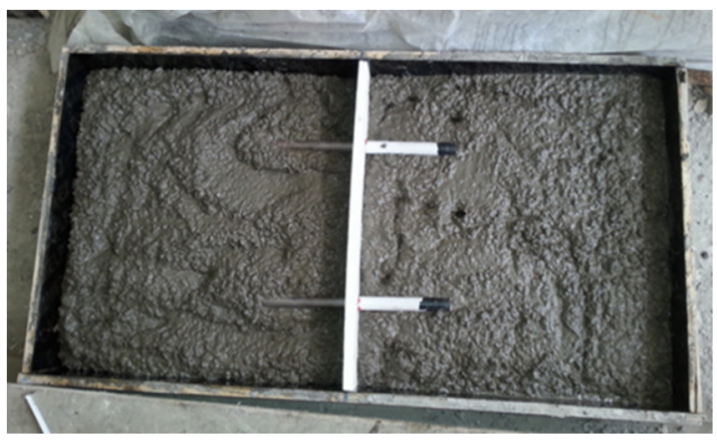

Fig. 2. Casting Process of Specimen.

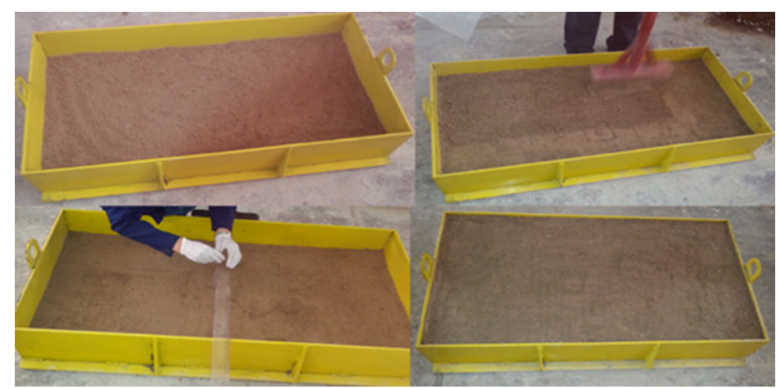

Fig. 3. Preparation of compacted Soil Layers.

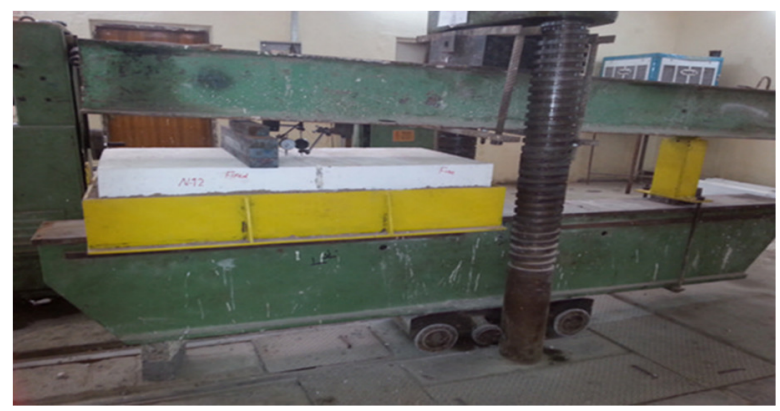

Fig. 4. Test of the Specimen on Subgrade Soil.

\section{Materials \\ 4.1 Cement}

In this study, Iraqi Portland cement (type V) of Tasluja factory which is named commercially (AL-GESR cement) was used, Cement has been tested and the results were compliant with the Iraqi standards IQ.S 5/1984.

\subsection{Fine Aggregate}

The natural river sand from Al-Sudoor region is used in concrete mix so as to achieve the midrange gradient specification. The fine aggregate gradation of the used sand which conforms to Iraqi specification I.Q.S 45/1984 and AASHTO T27-99.

\subsection{Coarse Aggregate}

The crushed gravel from AL-Niba'ee region is used in concrete mix so as to achieve the midrange gradient specification. the grading of the used coarse aggregate conforms to AASHTO M43-09, No. 67.

\subsection{Steel Dowel Bars}

The used steel dowel bars were round and smooth. The steel dowel bars were supplied from local markets. In this study, three different diameters of steel dowel bar (12, 16 and $20 \mathrm{~mm}$ ) were used as shown in Figure (5). Table (2) shows Properties of the used steel dowel bars. Steel 
dowel bars tests were conducted at the National Center for Construction Laboratories and Research (NCCLR).

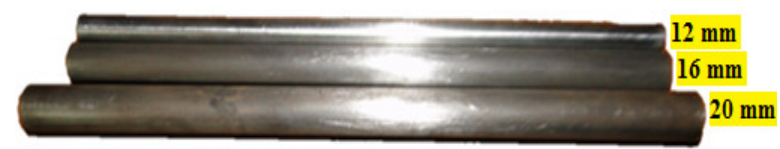

Fig. 5. Steel Dowel Bars.

Table 2,

Properties of Dowel Bars

\begin{tabular}{lllll}
\hline Diameter (mm) & $\begin{array}{l}\text { Yield Strength } \\
(\mathbf{M P a})\end{array}$ & $\begin{array}{l}\text { Ultimate Strength } \\
(\mathbf{M P a})\end{array}$ & $\begin{array}{l}\text { Elongation } \\
(\boldsymbol{\%})\end{array}$ & $\begin{array}{l}\text { Ultimate Load } \\
(\mathbf{k N})\end{array}$ \\
\hline 12 & 822 & 886 & 8.7 & 99.55 \\
16 & 709 & 756 & 11.5 & 153.84 \\
20 & 766 & 796 & 9.8 & 250.04 \\
\hline
\end{tabular}

\subsection{Soil}

In this study, two types of soil were used as a subgrade foundation layer. First type of soil (Type I) was taken from Al-jaafer region of Baghdad

Table 3,

Properties for Both Types of Soil. city and the second type (Type II) of soil taken from Al-salameaat region of Baghdad city. Table (3) shows the soil properties for each type.

\begin{tabular}{llll}
\hline Properties & specification & Type I & Type II \\
\hline plastic limit $(\%)$ & AASHTO T90 - 96 & 20.15 & 19.9 \\
liquid limit (\%) & AASHTO T89 - 96 & 35.22 & 46.4 \\
Plasticity Index & AASHTO T90 - 96 & 15.07 & 26.5 \\
optimum moisture content $(\%)$ & AASHTO T99 - 95 & 13 & 16 \\
Max. dry density $\left(\mathrm{g} / \mathrm{cm}^{3}\right)$ & AASHTO T99 - 95 & 1.8 & 1.85 \\
CBR value at optimum moisture content (\%) & AASHTO T193 - 93 & 7 & 5 \\
Soil classification & ASTM D3282 - 09 & A-6 & A-7-6 \\
\hline
\end{tabular}

\section{Concrete Mixture Proportions}

The normal strength concrete (NSC) was used in this study. Based on several trials mixes with each mix, control specimens three cubes with dimensions $150 * 150 * 150 \mathrm{~mm}$ and three prisms with dimensions $100 * 100 * 500 \mathrm{~mm}$ were cast to determine compressive strength and modulus of rupture, respectively. Table (4) shows mix proportions per cubic meter for normal type of concrete and Table (5) shows details of the specimens.

Table 4,

Proportions of Mix Per Cubic Meter

\begin{tabular}{ll}
\hline Material & $\begin{array}{l}\text { Normal strength } \\
\text { concrete }\end{array}$ \\
\hline Cement $\left(\mathrm{kg} / \mathrm{m}^{3}\right)$ & 400 \\
Sand $\left(\mathrm{kg} / \mathrm{m}^{3}\right)$ & 600 \\
Gravel $\left(\mathrm{kg} / \mathrm{m}^{3}\right)$ & 1200 \\
W/c & 0.5 \\
\hline
\end{tabular}

Table 5,

Details of the Specimens

\begin{tabular}{llll}
\hline $\begin{array}{l}\text { Specimen } \\
\text { designation }\end{array}$ & $\begin{array}{l}\text { Type of } \\
\text { subgrade } \\
\text { soil }\end{array}$ & $\begin{array}{l}\text { diameter of } \\
\text { steel dowel } \\
\text { bar }(\mathbf{m m})\end{array}$ & $\begin{array}{l}\text { Length of } \\
\text { steel dowel } \\
\text { bar }(\mathbf{m m})^{*}\end{array}$ \\
\hline N-12-I & A-6 & 12 & 300 \\
N-16-I & A-6 & 16 & 300 \\
N-16-II & A-7-5 & 16 & 300 \\
N-20-I & A-6 & 20 & 350 \\
\hline
\end{tabular}

*The length of the steel dowel bars used as recommended by the ACI 330R

\section{General Behavior of the Tested Specimens}

Generally, similar behavior was observed in all the tested specimens under loading. The load was applied from zero with $(10 \mathrm{kN})$ increments. Up to approximately ( $20 \%$ to $25 \%$ ) of ultimate load, the concrete slabs show no downward deflection on both edges of the joint, after that the concrete 
slabs start to move upward on both sides of the applied load due to dowel bar bending, this uplift is clearly observed at slabs far ends. This is because that the far ends of the slabs were unrestrained and free to move upward. With increasing loads, dowels continue to exert bearing stresses on to the underneath concrete and consequently uplift continues until failure of the loaded slab which characterized by flexural crack approximately under or adjacent to the applied load, see Figure (6).

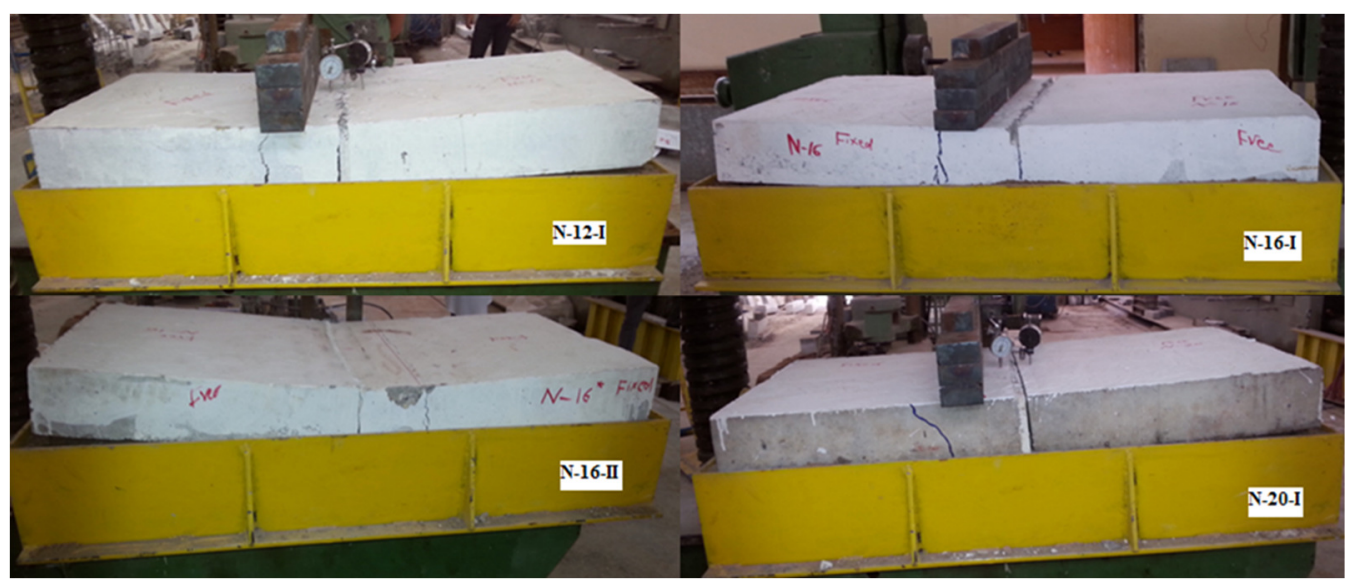

Fig. 6. The Tested Specimens at Failure.

\section{Mechanical Load Transfer Between Dowel and Concrete}

The load transfer mechanism between the dowel and the concrete is a complex phenomenon [6]. The dowel bar-concrete bearing stress can be calculated by the equation (1) depending on the assumption, that the embedded dowel bar behaves as beam on elastic foundation [7] .

$\sigma_{\mathrm{b}}=\mathrm{k}_{\mathrm{o}} \mathrm{y}$

Where:

$\sigma_{\mathrm{b}}$ : Bearing stress (MPa)

$\mathrm{k}_{\mathrm{o}}$ : Dowel support modulus $\left(\mathrm{N} / \mathrm{mm}^{\wedge} 2\right)$

$\mathrm{y}$ : Deflection of dowel bar $(\mathrm{mm})$

The pressure on the dowel bar which causes deflection in the concrete pavement of $(1 \mathrm{~mm})$ this is known as the modulus of the dowel support $\left(\mathrm{k}_{\mathrm{o}}\right)$. This means, the dowel bar modulus represents the properties of elastic in the dowel bar. The modulus of dowel support is affected by several factors which are diameter and shape of the dowel, yield strength of the dowel bars, concrete depth under the dowel, compressive strength of the concrete, elastic modulus of concrete and load ]8[. According to Yoder [6] and Huang ]9[ the modulus of dowel support ( $\mathrm{k}_{\mathrm{o}}$ ) is assumed from 300000 to $1500000 \mathrm{pci}(81.5$ to $409 \mathrm{GN} / \mathrm{m}^{3}$ ) because the value of dowel support modulus is difficult to find them. When contact between the steel dowel and the surrounding concrete is good, high value of dowel support modulus is assumed, but the contact between the steel dowel and the surrounding concrete deteriorates with repeated wheel loads, the concrete with time and repeated load may be crushed and created the voids around the dowels and lead to dowel looseness (DL).

In this study, the load is applied at distance $\mathrm{x}$ from joint face and distance c from end of dowel, see Figure (7).

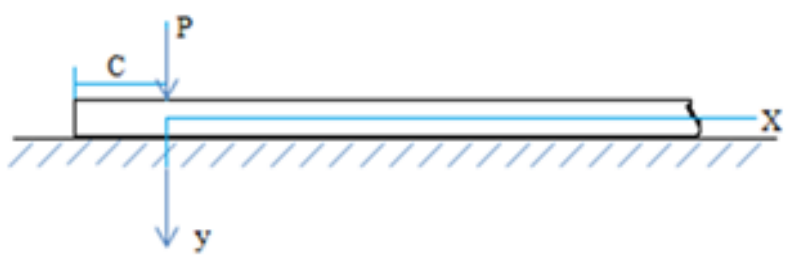

Fig. 7. The Beam on Elastic Foundation

So the deflection of the dowel bar can be calculated based on the theory of beam (dowel bar) on elastic foundation (concrete) [10] by equation below:

$$
\begin{aligned}
& y \quad=\frac{P \beta}{2 k_{o}} \quad e^{-\beta x}(\cos \beta x+\sin \beta x)+ \\
& \frac{e^{-\beta x}}{2 \beta^{3} E I}[(-V) \cos \beta(x+c)+\beta M(\cos \beta(x+ \\
& c) \sin \beta(x+c))] \\
& \text { Where: } \\
& \text { y: Deflection of dowel bar }(\mathrm{mm}) \\
& \beta \text { : Relative stiffness of the dowel bar }(1 / \mathrm{mm}) \\
& \text { E: Elastic modulus of dowel bar }\left(\mathrm{N} / \mathrm{mm}^{2}\right) \\
& \text { I: Moment of inertia of the dowel bar }\left(\mathrm{mm}^{4}\right)
\end{aligned}
$$


P: The transfer load $(\mathrm{N})$

$k_{o}$ : Modulus of dowel support $\left(\mathrm{N} / \mathrm{mm}^{2}\right)$

$\mathrm{x}$ : Distance along dowel measured from the point of the applied load $(\mathrm{mm})$

c: Distance from dowel end in the loaded slab to the point of load $(\mathrm{mm})$

M:Bending moment on dowel (N.mm)

$\mathrm{V}$ :Shearing force $(\mathrm{N})$

The relative stiffness of the dowel bar can be calculated using equation (3) [11]:

$\beta=\sqrt[4]{\frac{k}{4 E I}}$

According to Friberg [7] k can replaced by $k_{o} \mathrm{~d}$ and re-write as:

$\beta=\sqrt[4]{\frac{k_{o} d}{4 E I}}$

Where:

$\mathrm{k}$ : Modulus of foundation $(\mathrm{MPa} / \mathrm{mm})$

$k_{o}$ : Modulus of dowel support $\left(\mathrm{N} / \mathrm{mm}^{2}\right)$

$\mathrm{d}$ : Diameter of dowel bar (mm)

The length of dowel bar is assumed semi-infinite according to Friberg [7] . But the length of dowel bar is finite, so the equation above can be used if the $\beta \mathrm{L}$ is more than 2 [12].

The bending moment on dowel (M) and shearing force (V) can be calculated by equations (5) and (6), respectively [12]:

$M=-\frac{P}{4 \beta} e^{-\beta c}(\cos \beta c-\sin \beta c)$

$V=-\frac{P}{2} e^{-\beta c} \cos \beta c$

Figure (8) shows the distribution of bearing stress (calculated using Equation (1)) along the dowel bar of the specimen N-16-I (all other specimens have similar distribution). As shown in Figure 8 maximum bearing stress occurs under the applied load and decreases as the distance from the applied load increases until approximately the joint face where bearing stress, values become negligible.

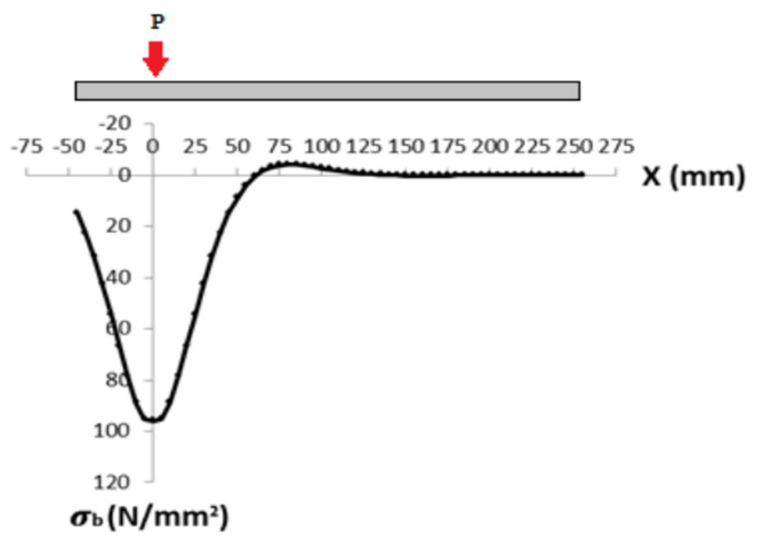

Fig. 8. Distribution of Bearing Stress along dowel bar for (N-16-I) Specimen

\section{Failure Mechanism of the Tested Specimens}

In general, all the specimens behaved elastically and did not show defects or cracks at low levels of load but when the load exceeds (20\% to $25 \%$ ) of the ultimate load the slabs started to uplift. Then the loaded slab failed suddenly by a tension crack generated at tension (bottom) face of concrete slab and propagated fast to the compression face splitting the loaded slab into two parts. However this is no to typical failure of concrete pavements and it happens because the edges of the concrete slabs were unrestricted as mentioned earlier.

The above described failure mechanism occurs when the induced tensile stress $\left(f_{t}\right)$ in the bottom face (under the load) exceeds the concrete ultimate tensile strength $\left(f_{t u}\right)$. To verify this assumption, the following approach is proposed:

Failure tensile stress $\left(f_{t}\right)$ has two components, namely: flexural tensile stress $\left(f_{t 1}\right)$ and splitting tensile stress $\left(f_{t 2}\right)$, flexural tensile stress is a result of the moments caused by the uplift bearing stresses ( $M_{\text {bearing }}$ ) minus the moments caused by concrete slabs weight $\left(M_{\text {weight }}\right)$, see Figure (9).

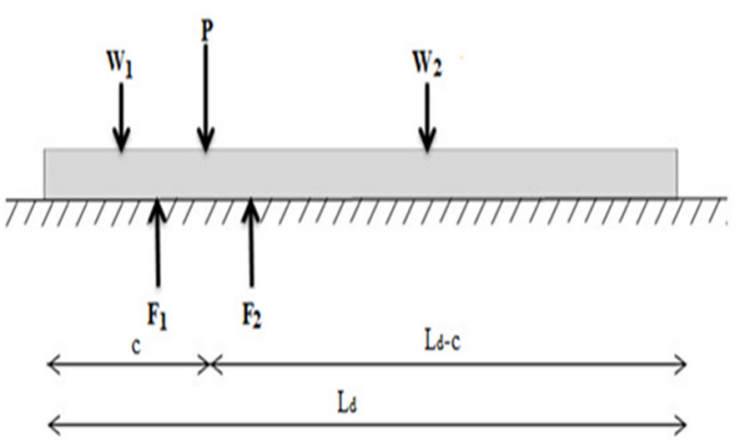

Fig. 9. The Flexural Tensile Stress.

$f_{t 1}$ can be calculated using flexural formula:

$f_{t 1}=\frac{M C}{I}$

$M=M_{\text {bearing }}-M_{\text {weight }}$

$M_{\text {bearing }}=F_{1} * \operatorname{arm}_{1}+F_{2} * \operatorname{arm}_{2}$

$F_{1}=\int_{0}^{c} \sigma_{b} d_{x}$

$F_{2}=\int_{0}^{L_{d}-c} \sigma_{b} d_{x}$

$\operatorname{arm}_{1}=\int_{0}^{c} \sigma_{b} \cdot x d_{x} / \int_{0}^{c} \sigma_{b} d_{x}$

$\operatorname{arm}_{2}=\int_{0}^{L_{d}-c} \sigma_{b} \cdot x d_{x} / \int_{0}^{L_{d}-c} \sigma_{b} d_{x}$

Where:

$F_{1}, F_{2}$ : Bearing uplift forces at two sides of the applied load.

$\mathrm{arm}_{1}$ : Distance from $F_{1}$ to $\mathrm{P}$. 
$\operatorname{arm}_{2}$ : Distance from $F_{2}$ to $\mathrm{P}$.

All the above integrals are evaluated numerically using trapezoidal rule with strip width of $5 \mathrm{~mm}$.

Splitting tensile stress $\left(f_{t 2}\right)$ is a lateral tensile stress acts along the slab depth as a result of the compressive stress under and at the section of the applied load, see Figure (10).

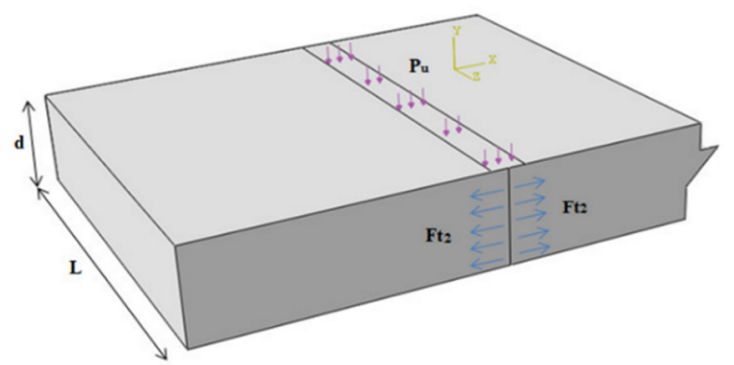

Fig. 10. The Splitting Tensile Stress. $f_{t 2}$ can be calculated by using Equation (14) [13]:

$f_{t 2}=\frac{2 P}{\pi d L}$

Where:

P: Applied load $(\mathrm{N})$

$\mathrm{d}$ : Depth of the slab (mm)

L: Width of the slab (mm)

Table (6) lists the calculated failure tensile stress $\left(f_{t}\right)$ as direct summing of $\left(f_{t 1}\right)$ and $\left(f_{t 2}\right)$ for comparison purpose with the ultimate tensile strength $\left(f_{t u}\right)$ which is $\left(3 / 4 f_{r}\right)[14]$.

Table 6,

The Results of the Mechanical Properties for the Experimental Models

\begin{tabular}{lllllllll}
\hline \multirow{2}{*}{ specimens } & $\mathbf{f}_{\mathbf{c}}^{\prime}$ & $\mathbf{f}_{\mathbf{r}}$ & $\mathbf{P}_{\mathbf{u}}$ & $\mathbf{f}_{\mathbf{t} 1} \cdot$ & $\mathbf{f}_{\mathbf{t} 2}:$ & $\mathbf{f}_{\mathbf{t}} \therefore$ & $\mathbf{f}_{\mathbf{t u}}::$ & $\mathbf{f}_{\mathbf{t}} / \mathbf{f}_{\mathbf{t u}}$ \\
\hline N-12-I & $\mathbf{M P a}$ & $\mathbf{M P a}$ & $\mathbf{k N}$ & $\mathbf{M P a}$ & $\mathbf{M P a}$ & $\mathbf{M P a}$ & $\mathbf{M P a}$ & 0.94 \\
N-16-I & 27 & 3.91 & 190 & 1.13 & 1.61 & 2.74 & 2.93 & 0.99 \\
N-20-I & 27 & 3.91 & 198 & 1.22 & 1.68 & 2.9 & 2.93 & 1.25 \\
N-16-II & 27 & 3.91 & 197 & 2 & 1.68 & 3.68 & 2.93 & 0.62 \\
\hline
\end{tabular}

. Eq. (4.7)

: Eq. (4.14)

$\therefore f_{t}=f_{t 1}+f_{t 2}$

$:: f_{t u}=\frac{3 f_{r}}{4}$

As shown in Table (6) specimens N-12-I and N-16-I failed when $f_{t}$ appreximatly reaches $f_{t u}$ (94\% and $99 \%$ of $f_{t u}$, respectively). Specimen N20-I failed at $f_{t}$ higher than $f_{t u}\left(f_{t} / f_{t u}=1.25\right)$ because the maximum size for dowel bar (diamater and length) increase the strength of specimen. Can be explained the induced crack at failure of specimen N-20-I which is start inclining under the applied load at the bottom and deviated toward the end of the dowel at the top and did not penetrate the slab depth vertically as observed in the other specimens, see Figure (6). Specimen N16-II failed at $f_{t}$ lower than $f_{t u}\left(f_{t} / f_{t u}=0.62\right)$ because that the weaker subgrade allows concrete slabs to move downward under load which may cause additional tensile stresses that are not considered in calculating $f_{t}$, so it can be concluded that Eq. (7) underestimates the actual flexural tensile stress at failure in specimen N-16II.

\section{Effect of Dowel Bar Diameter}

Although increasing dowel bar diameter reduces bearing stresses between bar and concrete, diameter has a very little effect on failure loads with only $5 \%$ increase when dowel bar diameter increases from $12 \mathrm{~mm}$ to $16 \mathrm{~mm}$ or $20 \mathrm{~mm}$ because the failure of the tested specimens was highly dependent on concrete strength as discussed in the previous section. However using $20 \mathrm{~mm}$ diameter of dowel bar N-20-I made the slab to fail with inclined tension crack unlike $12 \mathrm{~mm}$ and $16 \mathrm{~mm}$ diameters (N-12-I and N-16-I).

In general, the load-deflection behavior of specimens with three different dowel diameter $(12,16$ and $20 \mathrm{~mm})$ are similar, as shown in Figure (11). This comparable behavior assures no significant effect of dowel bar diameter on the load-deflection behavior of specimens tested in this experimental study. 


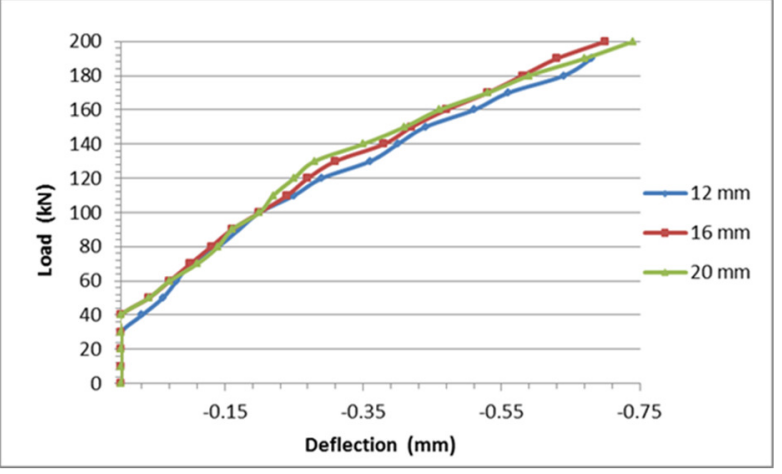

Fig. 11. Effect of Dowel Bar Diameter on LoadDeflection (Loaded Slab).

\section{Effect of Subgrade Soil}

The results show that using Type II $(\mathrm{CBR}=5 \%)$ gives lower failure load than Type I $(\mathrm{CBR}=7 \%)$ by $33 \%$, this implies the importance of subgrade support resistance (strength) on concrete pavements performance. This result is also illustrated in Figure (12) where Type I specimen (N-16-I) shows stiffer load-deflection behavior than Type II specimen (N-16-II).

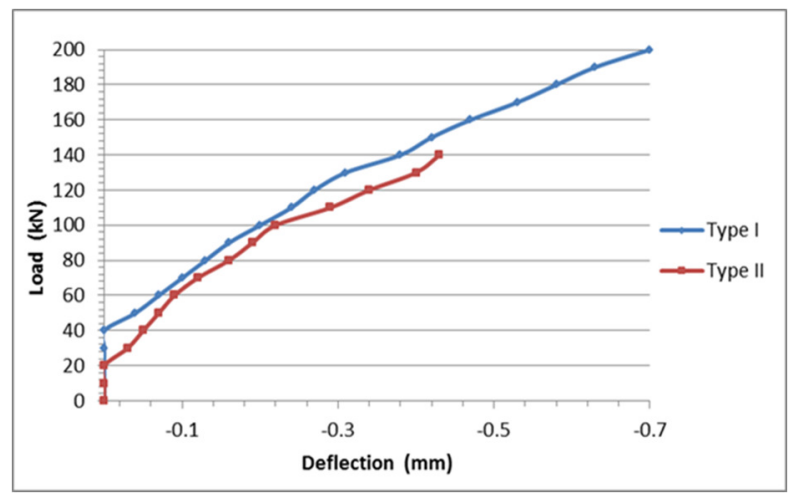

Fig. 12. Effect of Subgrade Type on Load-deflection (Loaded Slab).

\section{Creation and Analysis of the Finite Element Models by the ABAQUS/CAE}

To represent the specimens, 3-D geometry model of two layers (concrete slab and subgrade soil) of rigid pavement was used. The dimensions of a numerical models similar to the laboratory models dimensions which are $(1210 * 600 * 125$ $\mathrm{mm})$ dimensions of concrete slab, $(10 \mathrm{~mm})$ width of joint and $(200 \mathrm{~mm})$ depth of subgrade soil. In a numerical models, striping load is applied at (6 $\mathrm{cm}$ ) distance from edge joint (similar loading technique that are used in experimental models), see Figure (13). The value of load of each model applied at ultimate load.

Table (7) shown properties of material. The elastic modulus of subgrade soil determined by CBR value for soil that measured from experimental test according to the equation below [17]:

$\mathrm{MR}=2555^{*}(\mathrm{CBR})^{0.64}$

Where:

MR: Resilient Modulus of Subgrade (PSI).

CBR: California Bearing Ratio.

The elastic modulus of steel dowel bar was assumed and the elastic modulus of concrete measured from experimental test. The Poisson's ratio values for all materials are assumed according to Huang [9]. Three contact created between model parts, the first contact between Subgrade soil and concrete slab where the friction coefficient very small value was assumed, the second contact between each dowel bars and surrounding concrete in fixed side of slab and third contact also between each dowel bars and concrete surrounding but in free side of slab where the coefficient of friction $(0.35$ and 0.05 respectively) were assumed according to AlHumeidawi [15], see Figure (14). As already reminded in experimental work, the subgrade soil was put in the steel container on five layers compacted for a depth of steel container is (200 $\mathrm{mm})$. Therefore, the soil has become a solid block. The boundary condition of the subgrade soil is fixed. The concrete slab remained without the boundary condition (similar to the experimental models), see Figure (15).

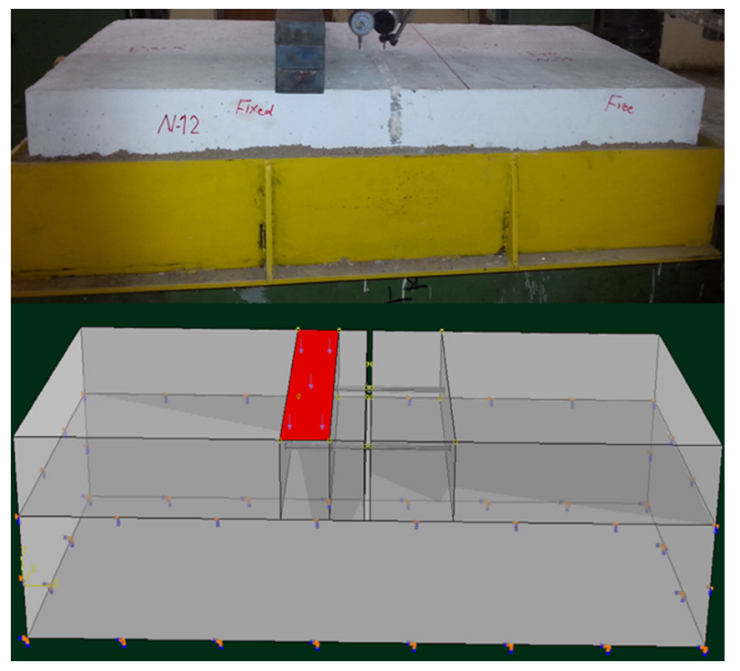

Fig. 13. 3-D General Geometry of the Concrete Pavement in ABAQUS. 
Table 7,

The Material Properties used in ABAQUS Models.

\begin{tabular}{|c|c|c|c|c|}
\hline Materials & & Elastic Modulus (E) $\quad \mathbf{k P a}$ & Poisson's Ratio $(\mu)$ & Properties of Material \\
\hline Subgrade Soil & $\begin{array}{l}\text { Type I (A-6) } \\
\text { Type II (A-7-6) }\end{array}$ & $\begin{array}{l}61000 \\
50000\end{array}$ & 0.45 & Isotropic and Linear Elastic \\
\hline $\begin{array}{l}\text { Concrete } \\
\text { Dowel bar }\end{array}$ & & $\begin{array}{l}24422000 \\
200000000\end{array}$ & $\begin{array}{l}0.15 \\
0.3\end{array}$ & $\begin{array}{l}\text { Isotropic and Linear Elastic } \\
\text { Isotropic and Linear Elastic }\end{array}$ \\
\hline
\end{tabular}

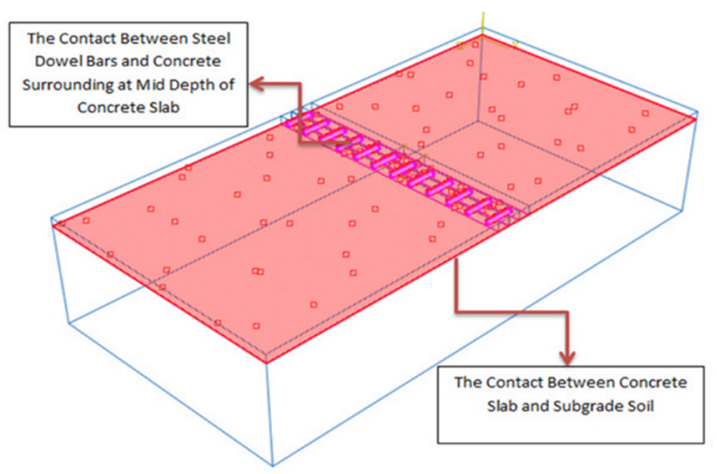

Fig. 14. The Contacts used in the Models.

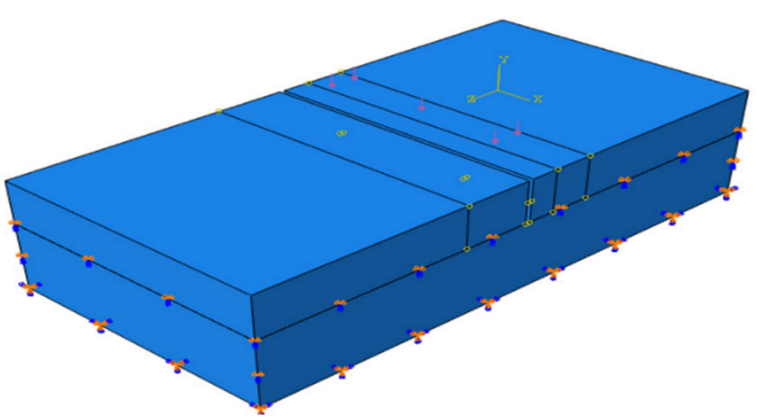

Fig. 15. The Boundary Condition of ABUQUS

Models.

\section{ABAQUS Program Results}

From the Figure (16), the load-deflection results behavior of loaded side $\left(\mathrm{d}_{1}\right)$ and unloaded side $\left(\mathrm{d}_{\mathrm{u}}\right)$ for experimental models and numerical models were have same behavior approximately. Table (8) show the ultimate deflection for loaded side $\left(d_{1}\right)$ and unloaded side $\left(d_{u}\right)$ where the difference between the numerical and experimental range from $(4.65 \%$ to $18.5 \%)$. Table (9) show the statistical analysis by T-test where the results have no significant difference between the experimental results and the numerical results for ultimate deflection at loaded side and unloaded side.

Table 8,

The comparison Between the Results of the Ultimate Deflection of Experimental and Numerical Models of Loaded Side ( $\left.d_{l}\right)$ and Unloaded Side $\left(d_{u}\right)$

\begin{tabular}{|c|c|c|c|c|c|c|}
\hline \multirow[t]{2}{*}{ Specimens } & \multicolumn{2}{|c|}{$\begin{array}{l}\text { Deflection of } \\
\text { ABAQUS Models } \\
(\mathrm{mm})\end{array}$} & \multicolumn{2}{|c|}{$\begin{array}{l}\text { Deflection of Experimental Models } \\
(\mathrm{mm})\end{array}$} & \multirow[t]{2}{*}{$\begin{array}{l}\text { Diff. } d_{l} * \\
(\%)\end{array}$} & \multirow[t]{2}{*}{$\begin{array}{l}\text { Diff. } \mathrm{d}_{\mathbf{u}} * * \\
(\%)\end{array}$} \\
\hline & $\mathrm{d}_{1}$ & $\mathrm{~d}_{\mathrm{u}}$ & $\mathrm{d}_{1}$ & $\mathrm{~d}_{\mathrm{u}}$ & & \\
\hline N-12-I & 0.63 & 0.17 & 0.68 & 0.19 & 7.35 & 10.52 \\
\hline N-16-I & 0.64 & 0.18 & 0.7 & 0.22 & 8.57 & 18.18 \\
\hline N-16-II & 0.41 & 0.12 & 0.43 & 0.14 & 4.65 & 14.29 \\
\hline N-20-I & 0.69 & 0.22 & 0.74 & 0.27 & 6.76 & 18.5 \\
\hline
\end{tabular}

* Diff. $d_{1}=\frac{d_{1_{A}}-d_{l_{E}}}{d_{l_{\mathrm{E}}}}$

$* *$ Diff. $\mathrm{d}_{\mathrm{u}}=\frac{\mathrm{d}_{\mathrm{u}_{\mathrm{A}}}-\mathrm{d}_{\mathrm{u}_{\mathrm{E}}}}{\mathrm{d}_{\mathrm{u}_{\mathrm{E}}}}$

Where:

Diff. $d_{1}$ : Difference of deflection between ABAQUS and experimental Models for loaded side.

Diff. $\mathrm{d}_{\mathrm{u}}$ : Difference of deflection between ABAQUS and experimental Models for unloaded side.

$\mathrm{d}_{\mathrm{l}_{\mathrm{A}}}$ : Deflection of loaded side for ABAQUS models.

$\mathrm{d}_{\mathrm{l}_{\mathrm{E}}}$ : Deflection of loaded side for experimental models.

$\mathrm{d}_{\mathrm{u}_{\mathrm{A}}}$ : Deflection of unloaded side for ABAQUS models.

$\mathrm{d}_{\mathrm{u}_{\mathrm{E}}}$ : Deflection of unloaded side for experimental models. 
Table 9,

The Statistical Analysis by T-test Results of the Ultimate Deflection of Experimental Models and Numerical Models

\begin{tabular}{llll}
\hline Side & T-test & T at $\alpha=0.05$ & Result \\
\hline loaded & 0.4737 & 1.9432 & insignificant \\
unloaded & 0.9511 & 1.9432 & insignificant \\
\hline
\end{tabular}
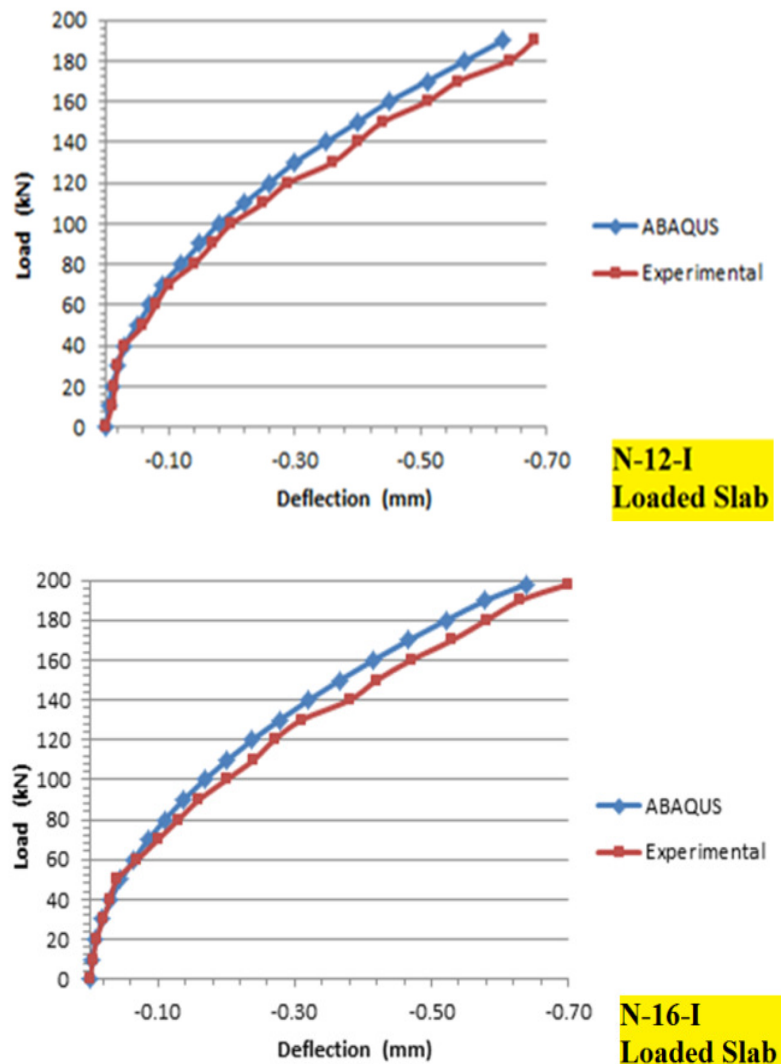

N-16-I

Loaded Slab

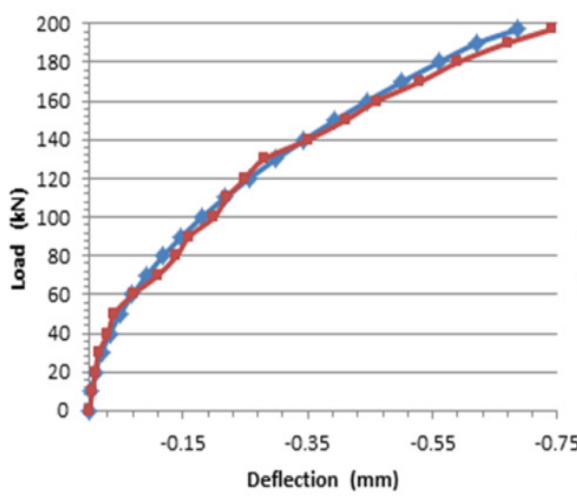

N-20-I Loaded Slab
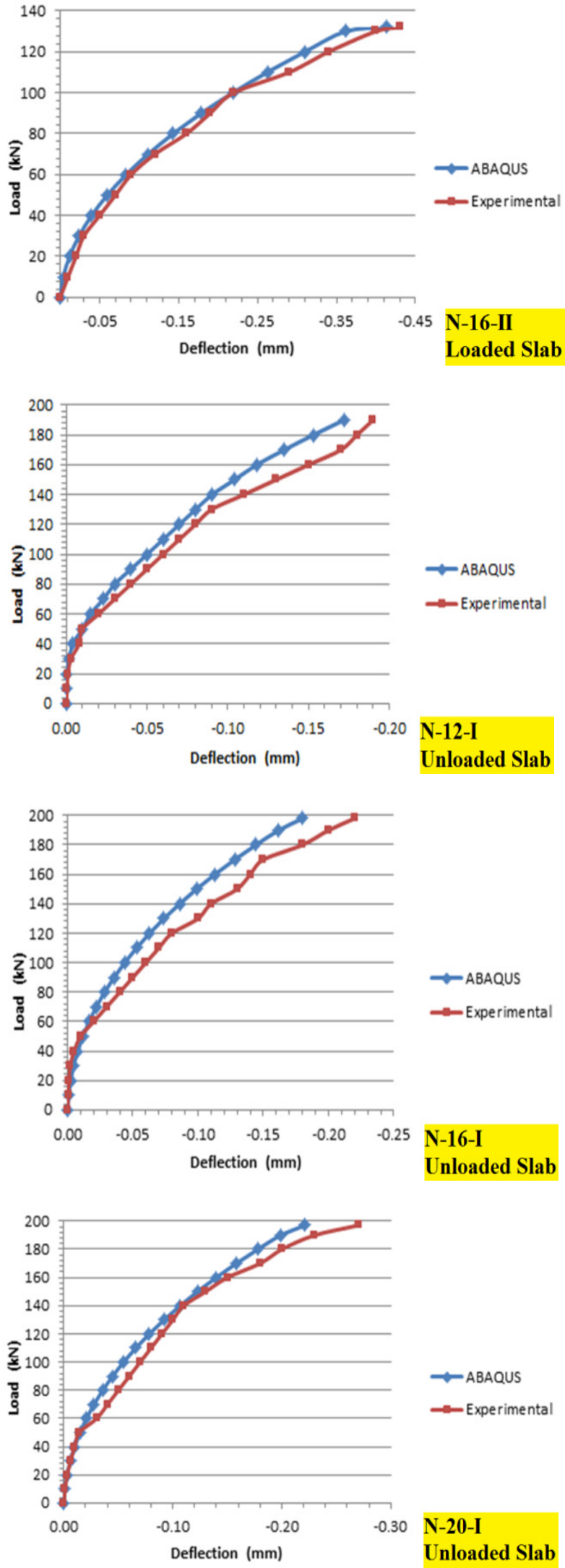


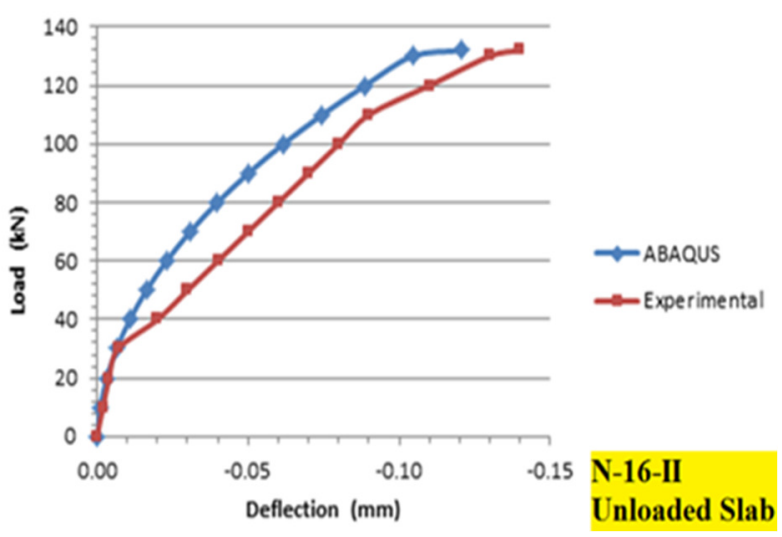

Fig. 16. The Behavior of Load-Deflection at Loaded and unloaded Sides for ABAQUS and Experimental Mode.

\section{Conclusions}

1. The behavior of load-deflection is similar for specimens tested with different size of dowel bars diameter $(12,16$ and $20 \mathrm{~mm})$ with little effect of diameter of dowel bar on the tested specimens behavior slightly stiffer behavior is observed as the dowel diameter increases from $12 \mathrm{~mm}$ to $20 \mathrm{~mm}$ with only $5 \%$ increase in failure load.

2. The CBR value of subgrade soil that supported the concrete slab in jointed plain concrete pavement effect the failure load and loaddeflection behavior where the soil Type II $(\mathrm{CBR}=5 \%)$ have failure load less than soil Type I by about $33 \%$.

3. Failure of the tested specimens was characterized by a flexural crack approximately under or adjacent to the applied load in the loaded concrete slab.

4. The numerical analysis by ABAQUS program shows numerical models were have same behavior of experimental models approximately and the statistical analysis by $\mathrm{T}$ test shows the results have no significant difference between the experimental results and the numerical results for ultimate deflection at loaded side and unloaded side.

\section{Notation}

AASHTO American Association of State Highway and Transportation Officials

ASTM American Concrete Institute ACPA American Society for Testing and Materials

\begin{tabular}{lll} 
I.Q.S & \multicolumn{2}{c}{ Iraqi Standards Specifications } \\
3-D FEM & Three Dimensional Finite \\
& Element Method & \\
CBR & California Bearing Ratio \\
W/C & Water/Cement Ratio \\
JPCP & Jointed Plain Concrete Pavement \\
JRCP & Jointed Reinforced Concrete \\
& Pavement & \\
CRCP & Continuously $\quad$ Reinforced \\
& Concrete Pavement
\end{tabular}

\section{References}

[1] Westergaard, H. M., "Stresses in Concrete Pavements Computed by Theoretical Analysis." Public Roads, Vol. 7, pp. 25 - 33, 1926.

[2] Hogg, A. and Hall, A., "Equilibrium of a Thin Plate Symmetrically Loaded, Resting on an Elastic Subgrade of Infinite Depth." Philosophical Magazine, Series 7, Vol. 25, 1938.

[3] Pickett, G and Ray, G. K., "Influence Charts for Concrete Pavements." American Society of Civil Engineers Transactions, American Society of Civil Engineers, Vol. 116, pp 4973, 1951.

[4] Chelliah Madasamy, lssam E. Harik, David L. Allen, L. John Fleckenstein, "Laboratory Testing and Analysis of Joints for Rigid Pavements." Research Report KTC-99- 22, 1999.

[5] American Concrete Pavement Association (ACPA), "Design and Construction of Joints for Concrete Highways." ACPA, Skokie, IL, $24 \mathrm{pp}, 1991$.

[6] Yoder, E. J., and M. W. Witczak. "Principles of Pavement Design" Second Edition, John Wiley and Sons, Inc., New Yolic, 1975.

[7] Friberg, B.F., "Design of Dowels in Transverse Joints of Concrete Pavements", Transactions, American Society of Civil Engineers. Vol.105, No. 2081, 1940.

[8] Friberg, B. F., "Design of Dowels in Transverse Joints of Concrete Pavements." Transactions, American Society of Civil Engineers, 105(2081), 140-161, 1938.

[9] Huang, Y. H., "Pavement Analysis and Design." 2nd edition, Prentice, Hall, Englewood Cliffs, New Jersey, 2004.

[10] Ansel C. Ugural and Saul K. Fenster, "Advanced and Applied Elasticity." Fourth edition, Prentice Hall, Upper saddle River, New Jersey, 2003. 
[11] Timoshenko, S., and Lessells, J. M., "Applied elasticity." Westinghouse technical night school press, 1925.

[12] Porter, M., Alberston, M., Barnes, B., Lorenz, E., and Viswanath, K., "Thermoset Composite Concrete Reinforcement." Report HR-325 Submitted to Project Development Division of the Iowa Department of Transportation and Iowa Highway Research Board, 1992.

[13] Neville AM, "Properties of concrete." 4th ed. Prentice Hall. Illinois, 2005.

[14] Raphael, J., "Tensile Strength of Concrete." ACI Materials Journal, No. 81-17, pp. 158165, 1984.

[15] Basim H. Al-Humeidawi," Evaluation of the Performance of GFRP Dowels in Jointed Plain Concrete Pavement (JPCP) for
Road/Airport under the Combined Effect of Dowel Misalignment and Cyclic Wheel Load

" $\mathrm{PhD}$ thesis, University of Manchester, USK, 2013.

[16] ACI Committee 224, "Joints in Concrete Construction" ACI 224.3R-95, American Concrete Institute, 1995.

[17] Witczak, M. W., Houston, W. N., \& Zapata, C. E., "Correlation of CBR Values with Soil Index Properties" Development of the 2002 Guide for the Design of New and Rehabilitated Pavement Structures, Technical Report. NCHRP Project,2001. 


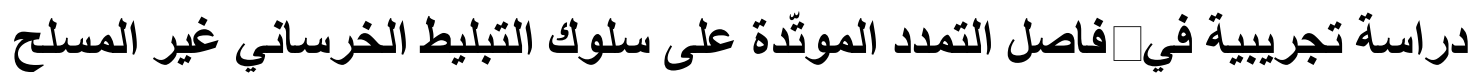

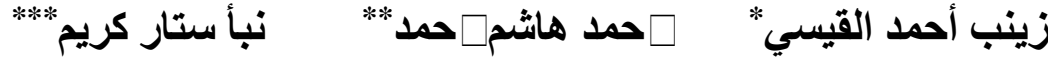

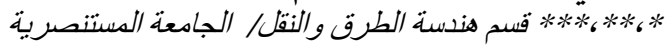

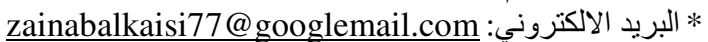 \\ m_sahlani@yahoo.com البريد الالكتروني: الإني \\ eng.nabaa1992@Gmail.com البريد الالكتروني: *** الاكتروني: ***
}

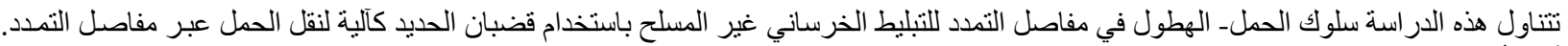

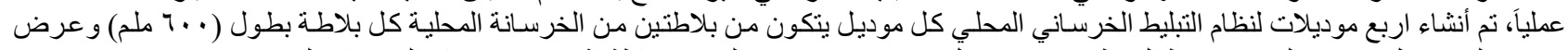

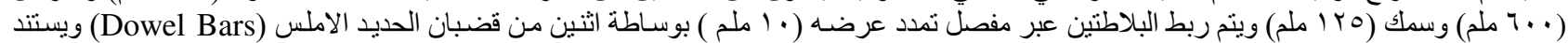

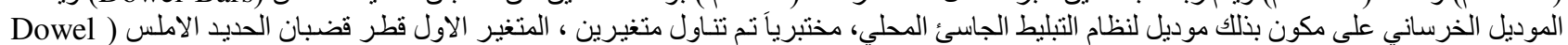

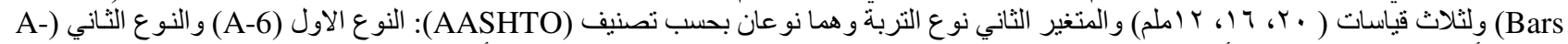

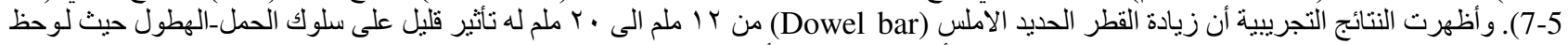

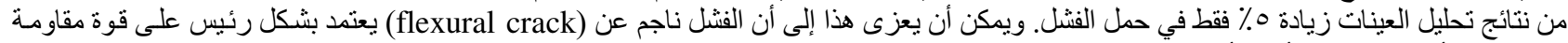

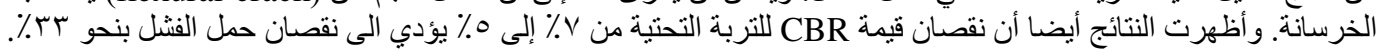

